\title{
Molecular analysis of dengue 3 viruses detected from dengue outbreak areas in southern Vietnam in 2010
}

\author{
Vu Thi Que Huong*, Vu Dinh Luan, Huynh Phuong Thao, Vu Thien Thu Ngu \\ From Institut Pasteur International Network Annual Scientific Meeting \\ Hong Kong. 22-23 November 2010
}

There are four dengue virus serotypes, based on molecular analysis. Each serotype is divided to several different genotypes, such as there are 5 genotypes in dengue virus serotype 3 (DENV-3), in which genotype II was confirmed to be the main etiology cause the big dengue fever/dengue hemorrhagic fever outbreak in Vietnam 1998.

Molecular epidemiological study was carried out on DENV-3, which causing dengue fever/dengue hemorrhagic fever in some epidemic areas with high morbidity and mortality from southern Vietnam in 2010. In this study, viral RNA of DENV-3 were extracted directly from dengue fever/dengue hemorrhagic fever patient sera, typing by RT-PCR (reverse transcriptase-polymerase chain reaction) with Lanciotti specific primers, sequencing the entire envelope (E) gene and comparative analysis with DENV-3 strain isolated from the big outbreak of dengue hemorrhagic fever in whole country in 1998. The phylogenetic analysis of DENV-3 from Vietnam as well as previously published strains, the results showed that: Vietnamese DENV-3 belong to genotype II among 5 genotypes classified for worldwide DENV-3 and have been closely related to Thailand isolates. Further researchs need to be carried out in order to confirm the evidence for local genetic evolution and conserved functional structure of E protein of DENV-3.

Published: 10 January 2011

* Correspondence: quehuong@pasteur-hcm.org.vn

Pasteur Institute of Ho Chi Minh City, Vietnam
doi:10.1186/1753-6561-5-S1-P50

Cite this article as: Que Huong et al: Molecular analysis of dengue 3 viruses detected from dengue outbreak areas in southern Vietnam in 2010. BMC Proceedings 2011 5(Suppl 1):P50.
Submit your next manuscript to BioMed Central and take full advantage of:

- Convenient online submission

- Thorough peer review

- No space constraints or color figure charges

- Immediate publication on acceptance

- Inclusion in PubMed, CAS, Scopus and Google Scholar

- Research which is freely available for redistribution
Biomed Central

\section{C) Biomed Central}

(c) 2011 Que Huong et al; licensee BioMed Central Ltd. This is an open access article distributed under the terms of the Creative Commons Attribution License (http://creativecommons.org/licenses/by/2.0), which permits unrestricted use, distribution, and reproduction in any medium, provided the original work is properly cited. 